Journal of Pragmatics Research

Vol. 3, No. 2 (2021), pp.108-130

E-ISSN: $2656-8020$

Website: http://e-journal.iainsalatiga.ac.id/index.php/jopr/index

\title{
Persuasive Strategies in Selected Brand Products' Advertisement on Instagram: Rationalization Aspect
}

\author{
Tira Nur Fitria ${ }^{1 *}$ \\ Institut Teknologi Bisnis AAS Indonesia ${ }^{1}$
}

${ }^{*}$ Corresponding Author

Email: tiranurfitria@gmail.com

DOI: http://dx.doi.org/10.18326/jopr.v3i2.108-130

Copyright $(\mathrm{C}$ the Author (s)

\section{cc) (†) (?)}

This work is licensed under a Creative Commons Attribution-ShareAlike 4.0 International License. How to Cite: Fitria, T. (2021). Persuasive Strategies in Selected Brand Products' Advertisement on Instagram: Rationalization Aspect. Journal of Pragmatics Research, 3(2). doi:https://doi.org/10.18326/jopr.v3i2.108-130

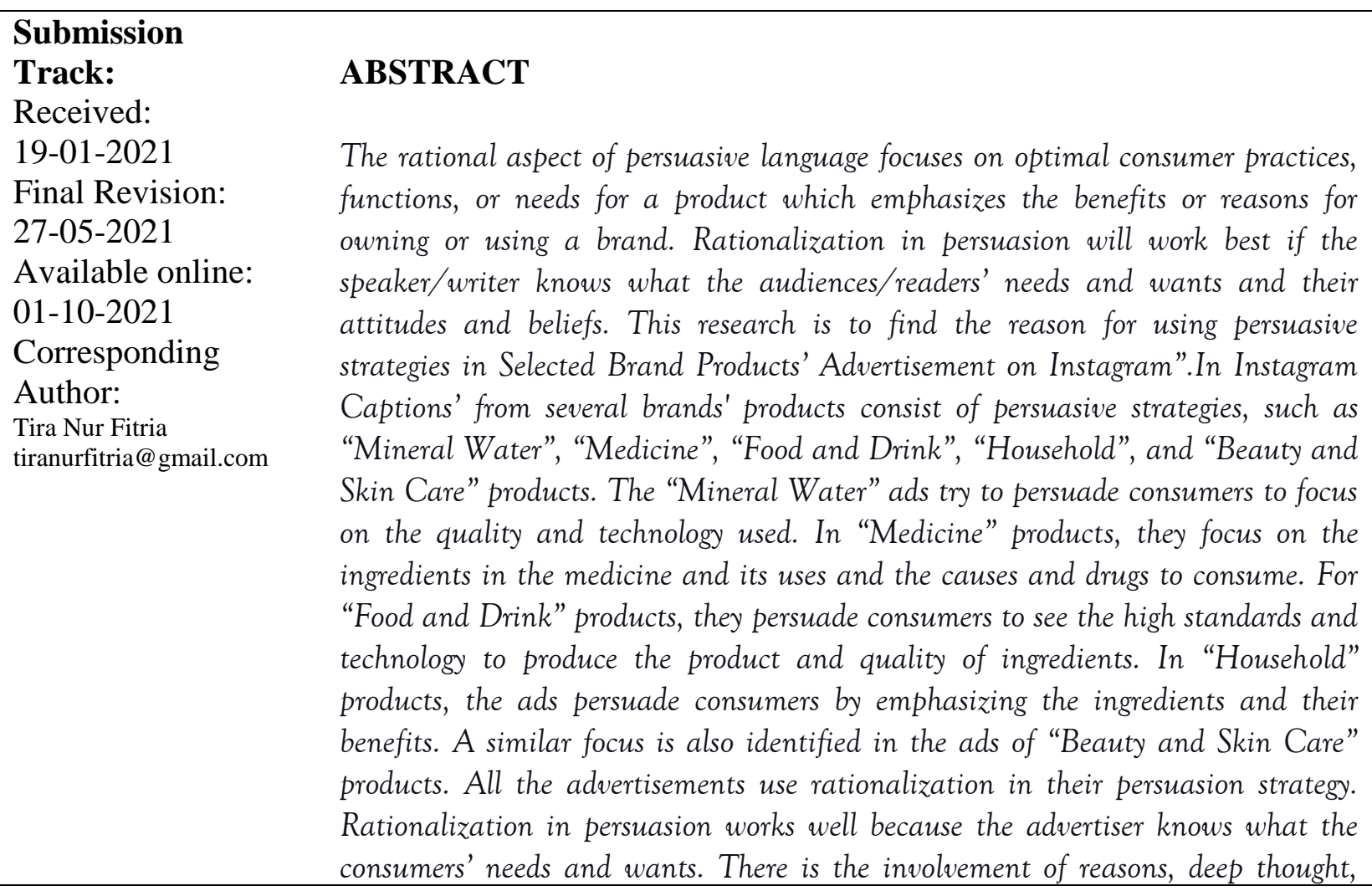


Journal of Pragmatics Research

Vol. 3, No. 2 (2021), pp.108-130

E-ISSN: $2656-8020$

Website: http://e-journal.iainsalatiga.ac.id/index.php/jopr/index

making a sense, and logical statements expected to be acceptable in the consumers' mind.

Keywords: persuasive strategies, rationalization, advertisement, product, Instagram

\section{INTRODUCTION}

Speech activity is a form of discourse that consists of speech act, such as declarative, directive speech acts, etc. (Fitria, 2015), According to Onuf (2013), directive speech acts are recognizable as imperatives. Pauwelyn et al., (2012, p. 168), states that the purpose of the directive speech act is to oblige someone else to perform some act, then the other purpose of directive speech acts is to influence the intentional behavior of the hearer (Haverkate, 2002, p. 7). The speaker, via a directive sentence, makes a speech act to achieve a certain communicative goal, namely to persuade the hearer in the inevitability of a future situation (Krapova \& Joseph, 2018). As stated by Johansen \& Larsen (2005), the directive is one speech act by means we commit ourselves and the partner in the conversation to future actions. Directives are useful because they allow the hearer to attain the goals by persuading or pushing other people to act according to our wishes,...(Pérez-Hernández, 2020).

Each type of directive shows a different purpose and function (Fitria, 2019b). Acts such as convincing or persuading belong to this category of directive speech act (Łyda \& Drożdż, 2014, p. 181). In our daily, we consciously or not, we are often affected by others; opinion, acts, or behavior. Persuade is to convince somebody or cause somebody to do something/stop doing something. (Kardela et al., 2004). Persuasion is one of the important aspects of communication in a pragmatic field (Yue, 2009). While Finnemore \& Goldstein (2013) states that persuasion can involve appeals to interest and rightly understood (Goossens et al., 1995, p. 30). Some speech act especially persuasive has the effect of moving the hearers. Persuasion can be expressed by persuading into change opinion, to force to agree, or to persuade someone. Pérez-Hernández (2020, p. 152) states that in persuading, the speaker attempts to persuade the hearer about the benefits of the action, and he/she does it by appealing to his/her rationality by presenting the reasons, advantages, and benefits of the proposed action. According to Johansen \& Larsen (2005), the act of persuasion is precisely an attempt to act and to influence action by utterances 


\section{Journal of Pragmatics Research}

Vol. 3, No. 2 (2021), pp.108-130

E-ISSN: $2656-8020$

Website: http://e-journal.iainsalatiga.ac.id/index.php/jopr/index

both verbal and non-verbal. Aziz \& Othman (2020) define that persuasion acts are described as a stimulus that modifies, forms, or strengthens a response.

Persuasive discourse is an example of advertising language (Zhang \& Parvaresh, 2019, p. 56). Macarro \& Peñuelas (2014) define that commercial advertising as part of persuasion technique. In this modern era, advertising is one way to introduce goods or services offered by companies. Ads are made to attract consumer interest and increase sales. Advertisements are often associated with persuasive sentences because they have the same goal to appeal to and influence the readers.

In this modern era, we are presented with promotional media through social media because it is more effective and efficient. Currently, the use of social media is not just for posting photos or videos. Social media is also used to sell our business products. Sentences with product types and ensures that these sentences can arouse the curiosity of potential customers. Advertising uses language and words that persuade someone to be motivated or interested in using the products and services that have been offered. Advertising is often associated with persuasive communication because advertising aims to invite, encourage, influence. Persuasive communication is communication that is carried out to influence, change behavior, attitudes, and thinking patterns.

One of the social media that has the most influence on the sale of a business' product is Instagram. Instagram is a social media that has a big and important influence on a business. Until now, Instagram already has 700 million users, and every day around 60 million photos are shared and can give 1.6 billion likes. Serafinelli (2018, p. 90) states that Instagram is focused on the visual; specifically people gather together through images, they also can connect then share ideas. Instagram is the most popular application that is used for sharing photos and videos. Instagram is a place where we need to create a personal connection and communication with the audience (Bajaj, 2020). This is one of the reasons why Instagram has various benefits for business people to build and develop a business brand through 'persuasive communication'.

Persuasive communication used in advertisements is also carried out by informing consumers about the superiority of the product, displaying attractive images, providing unique slogans or special words, making attractive offers, choosing the appropriate media or place to 


\section{Journal of Pragmatics Research}

Vol. 3, No. 2 (2021), pp.108-130

E-ISSN: $2656-8020$

Website: http://e-journal.iainsalatiga.ac.id/index.php/jopr/index

display these advertisements. The places selected for ads are public places for everyone to see. Besides, the offers given are usually in the form of product discounts and product bonuses. Persuasive is used to convince, persuade, seduce, or persuade someone to want or desire to do the actions or activities that are conveyed by the author. In persuasive sentences, there is the meaning of an order that is conveyed indirectly (implied) or is not compelling. This is the difference between a persuasive sentence and an imperative sentence. Persuasive speech is used in promoting a product to the general public. This type of persuasive sentence must be carefully thought out and have high creativity value because it will affect the product being sold.

According to Keraf (2004), there are some persuasive techniques, which are rationalization, identification, suggestion, conformity, compensation, projection, and displacement. Persuasive techniques can be limited as a process of using reason to justify a problem, the basis or reason is not a direct cause of the problem. The truth that is spoken of in persuasion is not absolute, but only the truth that serves to lay the foundations and pave the way so that the desires, attitudes, beliefs, decisions, or actions that have been determined or taken can be justified. Rationalization in persuasion will work best if the speaker or writer knows what the audience or reader needs and wants, as well as their attitudes and beliefs. The characteristic that stands out in this technique is the involvement of reason or deep thought. Rationalization means make sense. This focuses on what the speaker is saying. In this strategy, the speaker needs statements that logic that can be accepted by the consumers. Rationalization shows something by giving some logical statement or reason that can be accepted by logic.

There is some previous study that has been published that is related to persuasive strategies. First, a study was written by Alfian et al. (2019) entitled "Persuasive Strategies Used by Dr. Zakir Naik in his Speech in Oxford Union with Theme "Islam and the 21st Century". This analysis aimed to identify the Persuasion Techniques used by Dr. Zakir Naik in his Oxford Union Speech on Islam and the 21st Century. Second, a study was written by Wijaya \& Tedjaatmadja (2017) entitled "Persuasive Strategies Used by Insurance Agents in Prospecting Customers Based on Age Factor". The purpose of this research was to define the persuasive strategies used by $\mathrm{X}$ insurance agents in the prospecting of clients and to expose the discrepancies and similarities between persuasive strategies used by an insurance agent in the 
Journal of Pragmatics Research

Vol. 3, No. 2 (2021), pp.108-130

E-ISSN: $2656-8020$

Website: http://e-journal.iainsalatiga.ac.id/index.php/jopr/index

prospecting of clients of the same age and older clients. Third, a study was written by Firmansyah \& Kuntjara (2016) entitled "Persuasive Strategies Used by Agung Sedayu Group in the Infomercial, Metro TV'. This research is carried out to find out the kinds of persuasion techniques that were used in the infomercial of the Agung Sedayu Party.

From the previous studies explained above, of course, there is difference and similarity with this research. The first research focuses on the persuasive strategy used in speech, in the second and third research focus on the persuasive strategy used by sales marketing. This research persuasive strategy used in social media such as Instagram captions of the selected brand products. Therefore, the objective of this research is to find the main reason for using persuasive strategies in Selected Brand Products' Advertisement on Instagram”.

\section{RESEARCH METHOD}

This is descriptive qualitative research. Qualitative research is a study that focuses on understanding the naturalistic setting, or everyday life, or of a certain phenomenon or person (Neergaard \& Ulhøi, 2007, p. 383). This research here focuses on the phenomenon in our daily life such as social media such as Instagram. The research uses a document in collecting data. The document in this research is in the form of captions used in Instagram. The document is related to the written texts and takes into account the document's physical condition, the handwriting or writing used (Given, 2008, p. 24). According to Given (2015, p. 96), documents can be used as the sole focus for data collection and analysis, or they may be used as tools within another data collection method to complement research. The researcher undertook some steps in analyzing data, such as opening Instagram, selecting the products, analyzing the language in Instagram, then analyzing the persuasive language in Instagram descriptively.

\section{Findings and Discussion}

\section{Findings}

There are some persuasive strategies found in Instagram's captions especially in the aspect of rationalization. The examples are as follow: 
Journal of Pragmatics Research

Vol. 3, No. 2 (2021), pp.108-130

E-ISSN: $2656-8020$

Website: http://e-journal.iainsalatiga.ac.id/index.php/jopr/index

Table 1. Persuasive Strategy Used in Mineral Water Product

No

Instagram Caption

1. $\quad$ sehataqua ${ }^{\circ}$ Sudah di penghujung tahun, apa resolusimu sudah tercapai?. Ayo mulai \#BijakBerplastik sebagai kebiasaan baru di tahun 2021! Lebih mudah \#BijakBerplastik dengan AQUA Life karena terbuat dari $100 \%$ dan dapat 100\% didaur ulang kembali. Selain pastinya lebih ramah lingkungan, AQUA Life sudah bersertifikasi BPOM, halal, dan memenuhi kriteria SNI dan FSCC 22000. Yang paling penting airnya berasal dari sumber yang terlindungi, sehingga kekayaan mineralnya terjaga. AQUA Life - untuk kebaikan alam dan kebaikan hidrasimu!

(Already at the end of the year, has your resolution been reached ?. Let's start \#BijakBerplastik as a new habit in 2021! It's easier to \#BijakBerplastik with AQUA Life because it's made of $100 \%$ and can be recycled $100 \%$. Apart from being more environmentally friendly, AQUA Life is BPOM certified, halal, and meets the SNI and FSCC 22000 criteria. The most important thing is that the water comes from protected sources so that its mineral wealth is preserved. AQUA Life - for the good of nature and the good of your hydration!)

2. le_mineraleid $\bullet$ Inget, Leminz, sebelum beli sepatu olahraga baru, pastikan kamu ikuti tips ini, ya! Karena beli yang bagus aja gak cukup, tapi harus yang nyaman dan sesuai dengan kebutuhan. Sama seperti Le Minerale, berasal dari sumber yang baik aja gak cukup, harus dikemas dengan Double Protection untuk memastikan mineralnya selalu terjaga sampai ke tangan kamu. Pilih Le Minerale karena ada seal cap-nya dan botolnya keras sebelum dibuka.

(Remember, Leminz, before buying new sneakers, make sure you follow these tips, OK! Because just buying a good one is not enough, but it must be comfortable and following your needs. Just like Le Minerale, it is not enough to come from a good source, it must be packed with Double Protection to ensure that the minerals are always kept up to your hands. Choose Le Minerale because it has a seal cap and the bottle is hard before opening).

3. nestlepurelife_id $\odot$ Selain standar kualitasnya Internasional, cuma Nestle Pure Life yang menggunakan mikrofiltrasi 0,2 mikron yang dapat menyaring berbagai macam bakteri dan virus patogen. Itu yang bikin Nestle Pure Life beda dari yang lain. Masih ragu untuk \#PilihPureLife?

(Besides an international quality standard, only Nestle Pure Life uses 0.2-micron microfiltration which can filter out various kinds of pathogenic bacteria and viruses. That's what makes Nestle Pure Life different from the others. Still unsure about \#PilihPureLife?)

4. $\quad$ pristine8.id $\diamond$ Pristiners, apa sih bedanya Pristine 8+ dengan air minum dalam kemasan lainnya? Jadi, selain pHnya yang tinggi, Pristine 8+ juga diproses dengan melewati dua kali proses penyaringan lho. Pertama, air yang berasal dari sumber mata air terpilih akan melalui proses filterisasi untuk membuang kotoran dan bakteri dan menghasilkan air siap minum. Tapi, meskipun sudah melalui proses penyaringan pertama, air kemudian lanjut lagi diproses dengan cara ionisasi untuk memisahkan sifat asam dan basa (pH tinggi) pada air. Nah, hasil akhir inilah yang kemudian jadi air minum pH tinggi kualitas terbaik dan masuk ke dalam setiap kemasan Pristine 8+. Jadi, udah minum Pristine 8+ belum hari ini?

(Pristiners, what is the difference between Pristine $8+$ and other bottled drinking water? So, apart from its high $\mathrm{pH}$, Pristine $8+$ is also processed by going through two filtering processes, you know. First, water from selected spring sources will go through a filtering process to remove dirt and bacteria and produce ready-todrink water. However, even though it has gone through the first filtering process, the water is then further processed by ionization to separate the acidic and alkaline (high $\mathrm{pH}$ ) properties of the water. Well, this final result then becomes the best quality high $\mathrm{pH}$ drinking water and goes into every Pristine 8+ packaging. So, have you taken Pristine $8+$ yet?)

5. Amidisindonesia $\bullet$ Air adalah salah satu faktor penting bagi tubuh agar kesehatan tetap terjaga. Maka dari itu berikan air dengan kualitas terbaik sehingga terhindar dari penyakit. Amidis merupakan satu - satunya di Indonesia Air Minum dengan Teknologi Distilasi 110C. Karena diproses menggunakan teknologi distilasi, Air Minum Amidis bebas Bakteri dan Virus, tanpa Mineral non-organik, bebas dari kontaminasi bahan berbahaya.

(Water is one of the important factors for the body so that health is maintained. Therefore, provide water of the highest quality so that you avoid disease. Amidis is the only Drinking Water in Indonesia with 110C 


\section{Journal of Pragmatics Research}

Vol. 3, No. 2 (2021), pp.108-130

E-ISSN: $2656-8020$

Website: http://e-journal.iainsalatiga.ac.id/index.php/jopr/index

Distillation Technology. Because it is processed using distillation technology, Amidis Drinking Water is free

of bacteria and viruses, without non-organic minerals, free from contamination of hazardous materials)

Based on the table 1, it can be seen that in advertisement number 1 is written "It's easier to \#BijakBerplastik with AQUA Life AQUA-Life because it is made from $100 \%$ and can be recycled $100 \%$. Besides being more environmentally friendly, AQUA Life is BPOM certified, halal, and meets the SNI and FSCC 22000 criteria. The most important thing is that the water comes from protected sources so that its mineral wealth is preserved. AQUA Life - for the good of nature and the good of your hydration!”. It shows that this advertisement tries to persuade consumers to focus on the quality and technology of the product such as environmentally friendly, AQUA Life is BPOM certified, halal, and meets the SNI and FSCC 22000 criteria. This is expected to be a differentiator from other similar products.

In advertisement number 2, is written "Le Minerale, from a good source, is not enough, it must be packed with Double Protection to ensure that the minerals are always kept in your hands. Choose Le Minerale because it has a seal cap and the bottle is hard before opening". It shows that this advertisement tries to persuade consumers to focus on the quality and technology of the product which its product is packed with Double Protection and shows that the package of the product cannot be opened easily to ensure the quality of minerals.

In advertisement number 3, is written "Apart from international quality standards, only Nestle Pure Life uses a microfiltration 0.2 micron which can filter out various kinds of pathogenic bacteria and viruses. That's what makes Nestle Pure Life different from the others. Still unsure about \#PilihPureLife?" It shows that this advertisement tries to persuade consumers to focus on the quality and technology of the product which goes International by using a process of Microfiltration, a kind of precision filtration technology that uses a filter with a pore size of $0.1-1.5 \mu \mathrm{m}$ to filter water.

In advertisement number 4 is written "Pristiners, what is the difference between Pristine 8+ and other bottled drinking water? Apart from its high $\mathrm{pH}$, Pristine $8+$ is also processed by going through two filtering processes, you know. Well, this final result then becomes the best quality high $\mathrm{pH}$ drinking water and goes into every Pristine $8+$ packaging". It shows that this advertisement tries to persuade consumers to focus on the quality and technology of the product. 


\section{Journal of Pragmatics Research}

Vol. 3, No. 2 (2021), pp.108-130

E-ISSN: $2656-8020$

Website: http://e-journal.iainsalatiga.ac.id/index.php/jopr/index

Such as, first, water from selected spring sources will go through a filtering process to remove dirt and bacteria and produce ready-to-drink water. However, even though it has gone through the first filtering process, the water is then further processed by ionization to separate the acidic and alkaline (high $\mathrm{pH})$ properties of the water.

In advertisement number 5 is written "Amidis is the only Drinking Water in Indonesia with 110C Distillation Technology. Because it is processed using distillation technology, Amidis Drinking Water is free of bacteria and viruses, without non-organic minerals, free from contamination of hazardous materials". It shows that this advertisement tries to persuade consumers to focus on the quality and technology of the product. It is processed with modern distillation technology, the water is boiled at a temperature of $110 \mathrm{C}$ so it is free from bacteria, viruses, and non-organic minerals that are not needed by the body.

Table 2. Persuasive Strategy Used in Medicine Product

\begin{tabular}{|c|c|}
\hline No & \\
\hline 1. & $\begin{array}{l}\text { antangin_id Selalu sedia Antangin di rumah yuk sebagai bentuk kasih ibu pada keluarga. } \\
\text { Dengan kandungan herbal Jahe, Royal Jelly, dan Ginseng, Antangin JRG melindungi kesehatan } \\
\text { keluarga ibu terutama selama pandemi dengan meningkatkan daya tahan tubuh dan mengatasi } \\
\text { masuk angin. Ibu sudah stok Antangin JRG di rumah? komen di bawah ya! Wes, ewes, ewes, } \\
\text { bablas angine! } \\
\text { (Always be ready for Antangin at home as a form of mother's love for the family. With the herbal } \\
\text { ingredients of Ginger, Royal Jelly, and Ginseng, Antangin JRG protects the health of the mother's } \\
\text { family, especially during a pandemic by increasing endurance and overcoming colds. Do you } \\
\text { already stock Antangin JRG at home? comment below! Wes, ewes, ewes, bablas angine!) }\end{array}$ \\
\hline 2. & $\begin{array}{l}\text { nadolid Setelah melewati tahun } 2020 \text { yang penuh dengan hal tidak terduga, kita harus } \\
\text { ngguh dalam menjalani hari-hari di tahun } 2021 \text { ini. Untuk itu, selalu sedia Panadol Extra ya! } \\
\text { emanTangguh dengan kandungan Parasetamol dan Kafein ini efektif untuk redakan sakit kepala } \\
\text { n berbagai nyeri yang mengganggu. Baca aturan pakainya terlebih dahulu. Jika sakit berlanjut, } \\
\text { gera hubungi dokter. Panadol sudah tersertifikasi Halal. } \\
\text { fter going through } 2020 \text { which was full of unexpected things, we must be resilient in going } \\
\text { ough the days of } 2021 \text {. For that, always have Panadol Extra available! \#TemanTuh with } \\
\text { racetamol and caffeine content is effective for relieving headaches and various annoying pains. } \\
\text { ad the rules of use first. If the pain persists, contact a doctor immediately. Panadol has been } \\
\text { tified Halal). }\end{array}$ \\
\hline 3. & ak_angin $\odot$ Saat gejala flu menyerang tuh rasanya gak enak banget deh! Kalau sudah \\
\hline
\end{tabular}




\title{
Journal of Pragmatics Research
}

Vol. 3, No. 2 (2021), pp.108-130

E-ISSN: $2656-8020$

Website: http://e-journal.iainsalatiga.ac.id/index.php/jopr/index

\begin{abstract}
dry throat, breathing begins to become obstructed, the body hurts to drink Tolak Angin Flu. Do you know that Rejecting the Colds contains Echinacea Flowers? This natural ingredient can reduce the risk of colds and of course, can increase the body's resistance to fight influenza, you know!)

4. redoxonid $\bullet$ Tahukah kamu kenapa Redoxon Triple Action baik untuk bantu jaga imunitasmu? Setiap tablet effervescent Redoxon Triple Action mengandung vitamin C dengan dosis tinggi 1000 mg yang baik untuk membantu menjaga daya tahan tubuh. Redoxon Triple Action juga mengandung 400iu Vitamin D dan 10mg Zinc yang bersinergi dengan Vitamin C untuk bantu jaga daya tahan tubuh. Selain itu, format effervescentnya lebih mudah diserap oleh tubuh karena dikonsumsi dalam bentuk cairan.

(Do you know why Redoxon Triple Action is good to help maintain your immunity? Each Redoxon Triple Action effervescent tablet contains a high dose of $1000 \mathrm{mg}$ of vitamin $\mathrm{C}$ which is good for helping to maintain endurance. Redoxon Triple Action also contains 400iu Vitamin D and 10mg Zinc which synergizes with Vitamin $\mathrm{C}$ to help maintain endurance. In addition, its effervescent format is more easily absorbed by the body because it is consumed in liquid form).
\end{abstract}

In advertisements, number 1, is written: "With the herbal ingredients of Ginger, Royal Jelly, and Ginseng, Antangin JRG protects the health of the mother's family, especially during a pandemic by increasing endurance and overcoming colds". It also shows that this advertisement tries to persuade consumers to focus on the ingredients in the medicine and its uses. This advertisement also tries to get consumers to focus on the causes and drugs that must be consumed. Here, the advertisement shows that the product contains natural ingredients such as Ginger, Royal Jelly, and Ginseng, which are blended into one. Ginger has properties to increase endurance, anti-oxidants, and warms the body, and also releases wind when we catch a cold. Royal Jelly is good for boosting the immune system from various diseases and can inhibit the growth of viruses and bacteria. Ginseng has properties that are more or less the same as ginger and is believed to increase endurance and increase stamina.

In advertisements number 2, is written "For that, always have Panadol Extra available! \#TemanTuh with Paracetamol and Caffeine content is effective for relieving headaches and various annoying pains. Panadol has been certified Halal". It also shows that this advertisement tries to persuade consumers to focus on the ingredients in the medicine and its uses. This advertisement also tries to get consumers to focus on the causes and drugs that must be consumed. Here, the advertisement shows that the product contains Paracetamol and Caffeine. Paracetamol is an analgesic that works by increasing the threshold of pain and Caffeine works by blocking the action of adenosine receptors thereby reducing pain. 


\section{Journal of Pragmatics Research}

Vol. 3, No. 2 (2021), pp.108-130

E-ISSN: $2656-8020$

Website: http://e-journal.iainsalatiga.ac.id/index.php/jopr/index

In advertisement number 3 is written "When flu symptoms strike, it doesn't feel really good! When you start to feel symptoms such as dry throat, breathing begins to become obstructed; the body hurts to drink Tolak Angin Flu. Do you know that rejecting the Flu contains Echinacea Flowers? These natural ingredients can reduce the risk of flu and of course, can increase the body's resistance to fight influenza". It also shows that this advertisement tries to persuade consumers to focus on the ingredients in the medicine and its uses. This advertisement also tries to get consumers to focus on the causes and drugs that must be consumed. Here, the advertisement shows that the product contains Echinacea plants that can prevent and treat colds; increase the production of white blood cells can fight infections in the body. This flower extract can shorten the duration of colds and other upper respiratory tract infections, as well as reduce their severity. This effect will occur if Echinacea is given immediately when symptoms of the disease appear.

In advertisement number 4 is written "Each Redoxon Triple Action effervescent tablet contains a high dose of $1000 \mathrm{mg}$ of vitamin $\mathrm{C}$ which is good for helping to maintain endurance. Redoxon Triple Action also contains 400iu Vitamin D and 10mg Zinc which synergizes with Vitamin $\mathrm{C}$ to help maintain body immunity. Besides its effervescent format is more easily absorbed by the body because it is consumed in liquid form". This advertisement also tries to get consumers to focus on the causes and medicines that must be consumed. Here, the advertisement shows that the product contains vitamin C, D, and Zinc.

\section{Table 3. Persuasive Strategy about Used in Food and Drink Product}

\begin{tabular}{ll}
\hline No & \multicolumn{1}{c}{ Instagram Caption } \\
\hline 1. & bangowarisankuliner $\bullet$ Tahun boleh berganti tetapi masakan asli nusantara tetap di hati. Apapun masakan \\
& yang Kawan Kuliner sajikan untuk keluarga tercinta, \#KelezatanAsli akan selalu hadir bersama kecap \\
& Bango. Terbuat dari kedelai hitam Mallika berkualitas serta menggunakan bahan alami seperti gula, garam, \\
dan air. Menghasilkan cita rasa masakan menjadi lebih nikmat. & \\
(Years may change, but the original Indonesian cuisine remains in the heart. Whatever dishes Kawan Kuliner \\
serves to your beloved family, \#KelezatanAsli will always be there with Bango soy sauce. Made from high- \\
quality Mallika black soybeans and uses natural ingredients such as sugar, salt, and water. Resulting in the \\
taste of cooking being more delicious). \\
\hline kopiluwakofficial ${ }^{\bullet}$ Cita Rasa Berkelas Kopi Berkualitas! Dengan bahan pilihan dan biji kopi asli, Kopi \\
Luwak Authentic Arabica hadir memberikan pengalaman menikmati kopi arabika terbaik untukmu. \\
Perpaduan kelezatan dan kegurihannya dikemas secara eksklusif. Kesan autentiknya pun tampak khas dan \\
berkelas. \\
(Taste Classy Quality Coffee! With selected ingredients and original coffee beans, Authentic Arabica Luwak
\end{tabular}


Journal of Pragmatics Research

Vol. 3, No. 2 (2021), pp.108-130

E-ISSN: $2656-8020$

Website: http://e-journal.iainsalatiga.ac.id/index.php/jopr/index

Coffee is here to provide you with the best Arabica coffee experience. The combination of delicacy and delicacy is packaged exclusively. The authentic impression looks distinctive and classy).

3. $\quad$ kapalapi_id Kopi Kapal Api berasal dari $100 \%$ biji kopi kualitas special yang diproses dengan standar dan teknologi tinggi sehingga menghasilkan Aroma dan Rasa Special yang dapat meningkatkan semangat kamu. Teman Ngopi, seberapa semangat kamu menghadapi kegiatan di hari ini?

(Kapal Api coffee comes from 100\% special quality coffee beans that are processed with high standards and technology to produce a special aroma and taste that can boost your enthusiasm. Friends of Coffee, how enthusiastic are you in facing today's activities?)

4. lemonilo $\bullet$ Siapa di sini yang suka banget sama Mie Instan Lemonilo Rasa Mie Goreng? Selain dibuat tanpa 3P, Mie Instan Lemonilo juga dibuat tanpa proses penggorengan (melainkan dipanggang), sehingga air rebusannya jernih. Oh ya, Lemonizen. Jangan lupa selalu membaca kandungan nutrisi yang ada di belakang bungkus makanan atau minuman yang akan kamu beli, ya. Hal ini agar kamu semakin aware dengan bahanbahan apa saja yang masuk ke dalam tubuhmu.

(Who here really likes Fried Noodle Flavor Lemonilo Instant Noodles? Besides being made without 3P, Lemonilo Instant Noodles are also made without the frying process (but are baked), so that the cooking water is clear. Oh yes, Lemonizen. Don't forget to always read the nutritional content that is on the back of the food or beverage packaging that you are going to buy. This is so that you are more aware of what ingredients enter your body).

5. $\quad$ mizone ${ }^{\ominus}$ Udah capek kerja masih belom weekend aja nih?? Minum Mizone Lychee Lemon dulu biar lo tetep semangat! Kandungan vitamin B3, B6 \& B12 bisa bantu lo balikin energi dan semangat lo lagi!.

(Are you tired of work, still haven't the weekend yet ?? Drink Mizone Lychee Lemon first to keep your spirits up! The content of vitamins B3, B6 \& B12 can help you to restore your energy and enthusiasm!).

6. $\quad$ sariwangi_id $\bullet$ Ini dia yang ditunggu-tunggu! Sariwangi dengan bangga menghadirkan SariWangi Teh Hitam, Jahe dan Kunyit. Teh yang mengandung kebaikan dari 3 bahan alami yang bisa bantu kamu jaga kesehatan tubuh. Aromanya yang hangat dan rasanya yang nikmat tentunya pas untuk menemani kamu di musim hujan ini.

(Here it is! Sariwangi is proud to present SariWangi Black Tea, Ginger, and Turmeric. Tea contains the goodness of 3 natural ingredients that can help you maintain a healthy body. The warm aroma and delicious taste are certainly right to accompany you in this rainy season).

7. miloindonesia ${ }^{\circ}$ Ibu-ibu sarapan berenergi itu penting untuk dukung aktivitas anak yang padat mulai dari berolahraga hingga belajar. Karena itu, lengkapi sarapannya dengan segelas energi MILO setiap hari! Kombinasi unik dari malt, susu dan cokelat yang diperkaya dengan 6 vitamin dan 3 mineral, bantu dukung ia tetap sehat dan aktif setiap hari!

(Energy breakfast mothers are important to support busy children's activities, from sports to learning. Therefore, complete the breakfast with a glass of MILO energy every day! A unique combination of malt, milk, and chocolate enriched with 6 vitamins and 3 minerals, help support her to stay healthy and active every day!).

8. anlene_indonesia $\bullet$ Sahabat Anlene, untuk tetap bergerak aktif menjalani aktivitasmu, kamu butuh asupan nutrisi yang tepat untuk dukung sehatnya ototmu. Yuk konsumsi Anlene Actifit dua gelas sehari dengan, kalsium, kolagen + vitamin c dan protein untuk bantu kuatkan tulang, sendi dan ototmu agar kamu tetap bebas bergerak, karena tiap gerakanmu berarti.

(Friends of Anlene, to stay active in your activities, you need the right nutrition to support the health of your muscles. Let's consume two glasses of Anlene Actifit a day with calcium, collagen + vitamin c, and protein to help strengthen your bones, joints, and muscles so that you are free to move, because your every move counts).

In advertisement number 1 is written "Years may change, but the original Indonesian cuisine remains in the heart. Whatever the dishes that Kawan Kuliner serves to your beloved family, \#KelezatanAsli will always be there with Bango soy sauce. Made from quality Mallika 


\section{Journal of Pragmatics Research}

Vol. 3, No. 2 (2021), pp.108-130

E-ISSN: $2656-8020$

Website: http://e-journal.iainsalatiga.ac.id/index.php/jopr/index

black soybeans and uses natural ingredients such as sugar, salt, and water. Produces a more delicious taste of food". It also shows that this advertisement tries to persuade consumers to focus on the quality of ingredients (Mallika black soybeans and natural ingredients) that can be consumed by consumers.

In advertisement number 2 is written "Taste Classy Quality Coffee! With selected ingredients and original coffee beans, Authentic Arabica Luwak Coffee is here to provide you with the best Arabica coffee experience. The combination of delicacy and delicacy is packaged exclusively. The authentic impression looks distinctive and classy. It also shows that this advertisement tries to persuade consumers to focus on the quality of ingredients (ingredients and original coffee beans) that can be consumed by consumers.

In advertisement number 3 is written "Kapal Api Coffee comes from 100\% special quality coffee beans that are processed with high standards and technology to produce a special aroma and taste that can boost your spirits. Friends of Coffee, how excited are you to face today's activities?". It also shows that this advertisement tries to persuade consumers to focus on the quality of ingredients (coffee beans) that can be consumed by consumers. This advertisement also shows the process with high standards and technology in producing the special aroma and taste of the product to be consumed.

In advertisement number 4 is written "Who here really likes Fried Noodle Flavor Lemonilo Instant Noodles? Besides being made without 3P, Lemonilo Instant Noodles are also made without the frying process (but are baked), so that the cooking water is clear. Oh yes, Lemonizen. Don't forget to always read the nutritional content that is on the back of the food or beverage packaging that you are going to buy. This is so that you are more aware of what ingredients enter your body". It also shows that this advertisement tries to persuade consumers to focus on the quality of technology of the product (without the frying process (but are baked), so the cooking water is clear) that can be consumed by consumers.

In advertisement number 5, is written "Drink Mizone Lychee Lemon first to keep your spirits up! The content of vitamins B3, B6 \& B12 can help you to restore your energy and enthusiasm!". It shows that this advertisement tries to persuade consumers to focus on the ingredients in it and its benefits. Here, the advertisement shows that Vitamin B plays an 


\section{Journal of Pragmatics Research}

Vol. 3, No. 2 (2021), pp.108-130

E-ISSN: $2656-8020$

Website: http://e-journal.iainsalatiga.ac.id/index.php/jopr/index

important role in the body. This substance can help growth, development, and other body functions. Vitamin B3 can keep the nervous system working properly, maintain healthy skin, and convert food into energy. Vitamin B6 also plays a role in converting protein and carbohydrates from food into energy. Vitamin B12 has benefits for increasing the production of red blood cells, as well as brain and nervous system function. It also plays a role in protein and fat metabolism.

In advertisement number 6, Sariwangi is proud to present Sari Wangi Black Tea, Ginger, and Turmeric. Tea contains the goodness of 3 natural ingredients that can help you maintain a healthy body. The warm aroma and delicious taste are certainly right to accompany you in this rainy season. It shows that this advertisement tries to persuade consumers to focus on the ingredients in it and its benefits. Here, the advertisement shows that Black tea is useful for increasing the growth of good bacteria in the intestines so that it can maintain the health of the digestive tract. Ginger contains properties to help maintain endurance and helps reduce blood viscosity, lowers high blood pressure and high cholesterol, and helps to feel full longer. Turmeric is efficacious for maintaining a healthy digestive tract.

In advertisement number 7 is written "Energy breakfast mothers are important to support busy children's activities, from sports to learning. Therefore, complete the breakfast with a glass of MILO energy every day! A unique combination of malt, milk, and chocolate enriched with 6 vitamins and 3 minerals, help support her to stay healthy and active every day!”. It shows that this advertisement tries to persuade consumers to focus on the ingredients in it and its benefits. The advertisement shows that the product is made from malt, milk, and chocolate with 6 vitamins and 3 minerals. A glass of product consists of Protomalt, Vitamins, and Minerals. So, MILO is high in Calcium, Phosphorus, Iron, also high in Vitamins B2, B3, B6, B12, C, and D.

In advertisement 8 is written "Friends of Anlene, to stay active in your activities, you need the right nutrition to support the health of your muscles. Let's consume two glasses of Anlene Actifit a day with calcium, collagen + vitamin c, and protein to help strengthen your bones, joints, and muscles so that you are free to move because your every move counts. It shows that this advertisement tries to persuade consumers to focus on the ingredients in it and its benefits. The advertisement shows that the product is made from calcium, collagen, vitamin $\mathrm{C}$, and protein to help strengthen the parts of the body such as bones, joints, and muscles. 
Journal of Pragmatics Research

Vol. 3, No. 2 (2021), pp.108-130

E-ISSN: $2656-8020$

Website: http://e-journal.iainsalatiga.ac.id/index.php/jopr/index

In advertisement 5 is written "Imagine that every day your body is given nutritious food like Energen! The nutritional content in Energen which is equipped with Vitamin $C$ to maintain endurance and Extra Vitamin E and B Complex which provide extra energy makes Energen good to drink to complete the foundation of the morning". It shows that this advertisement tries to persuade consumers to focus on the ingredients in it and its benefits. The advertisement shows that the product is made from Vitamin C, Vitamin E, and B complex.

\section{Table 3. Persuasive Strategy Used in Household Products}

\begin{tabular}{|c|c|}
\hline \begin{tabular}{|l} 
No \\
\end{tabular} & Instagram Caption \\
\hline 1. & $\begin{array}{l}\text { rinso }{ }^{\circ} \text { Teman Rinso, dengan kesibukan sehari-hari, kadang suka khawatir nggak nih gimana memastikan } \\
\text { pakaian betul-betul bersih dari kuman \& virus? Nggak perlu khawatir lagi Teman Rinso, kini ada Rinso } \\
\text { Laundry Disinfektan, produk disinfektan pertama di Indonesia yang diformulasikan khusus untuk pakaian! } \\
\text { Dengan kandungan Hydrogen Peroxide dan Benzalkonium Chloride, 10x lebih efektif membunuh kuman \& } \\
\text { telah diuji terhadap virus Corona! Pakai Rinso Laundry Disinfektan, baju kesayangan Teman Rinso dijamin } \\
\text { bersih serta bebas dari kuman \& virus! Swipe ke kanan untuk tahu cara penggunaannya yah! } \\
\text { (Friends of Rinso, with their daily activities, sometimes are worried. How do you make sure your clothes are } \\
\text { really clean from germs \& viruses? No need to worry anymore Friends Rinso, now there is Rinso Laundry } \\
\text { Disinfectant, the first disinfectant product in Indonesia specially formulated for clothes! With the content of } \\
\text { Hydrogen Peroxide and Benzalkonium Chloride, 10x more effective at killing germs \& has been tested } \\
\text { against the Coronavirus! Use Rinso Laundry Disinfectant, Friends Rinso's favorite clothes are guaranteed to } \\
\text { be clean and free from germs \& viruses! Swipe right to see how to use it!). }\end{array}$ \\
\hline 2. & $\begin{array}{l}\text { tanyapepsodent } 0 \text { Pepsodent Complete } 8 \text {, dengan formula Zinc Mineral yang mampu membersihkan 99\% } \\
\text { bakteri jahat yang bersembunyi pada seluruh area mulut. Cukup hanya } 1 \text { pasta gigi bisa memberikan kamu } \\
\text { dan keluarga } 8 \text { manfaat sekaligus juga mampu melindungi senyum terbaikmu hingga } 18 \text { JAM! Pepsodent } \\
\text { Complete } 8 \text { siap memberikan \#PerlindunganMenyeluruh untuk senyummu dan keluarga. } \\
\text { (Pepsodent Complete } 8 \text {, with a Zinc Mineral formula that can clean } 99 \% \text { of bad bacteria that hide in the } \\
\text { entire mouth area. Just } 1 \text { toothpaste can give you and your family } 8 \text { benefits while protecting your best smile } \\
\text { for up to } 18 \text { HOURS! Pepsodent Complete } 8 \text { is ready to provide \#Covering protection for your smile and } \\
\text { your family). }\end{array}$ \\
\hline 3. & $\begin{array}{l}\text { zwitsal_id Selain menjaga kebersihan tubuh Si Kecil saat dan setelah mandi dengan Zwitsal, pastikan } \\
\text { Bunda memberinya perlindungan ekstra dengan produk-produk Zwitsal lainnya, ya. Seperti menjaga } \\
\text { pakaian Si Kecil juga sangat penting untuk dilakukan. Yuk gunakan Zwitsal Baby Fabric Detergent dan } \\
\text { Zwitsal Baby Fabric Softener dengan aroma khas Zwitsal. Pembersih dan pelembut pakaian ini mengandung } \\
\text { Green Tea dan Aloe Vera, sehingga kedua produk ini membuat pakaian Si Kecil lembut, wangi dan nyaman } \\
\text { untuk dipakai. } \\
\text { (Apart from keeping your little one's body clean during and after bathing with Zwitsal, make sure you give } \\
\text { him extra protection with other Zwitsal products. Like keeping your little one's clothes, it is also very } \\
\text { important to do. Let's use Zwitsal Baby Fabric Detergent and Zwitsal Baby Fabric Softener with a distinctive } \\
\text { Zwitsal aroma. This cleanser and fabric softener contains Green Tea and Aloe Vera, so these two products }\end{array}$ \\
\hline
\end{tabular}

In advertisement number 1, is written "Now there is Rinso Laundry Disinfectant, the first disinfectant product in Indonesia specially formulated for clothes! With the content of Hydrogen 
Journal of Pragmatics Research

Vol. 3, No. 2 (2021), pp.108-130

E-ISSN: $2656-8020$

Website: http://e-journal.iainsalatiga.ac.id/index.php/jopr/index

Peroxide and Benzalkonium Chloride, 10x more effective at killing germs \& has been tested against the Coronavirus! Use Rinso Laundry Disinfectant, Friends Rinso's favorite clothes are guaranteed to be clean and free from germs \& viruses!”. It also shows that this advertisement tries to persuade consumers to focus on the ingredients in it and its uses. Here, the advertisement shows that Hydrogen Peroxide and Benzalkonium Chloride is a compound found in many household products. These are generally contained in antiseptic products and concentrations of the active ingredient suitable for disinfection which can inhibit the growth of microorganisms, and even kill germs.

In advertisement number 2 is written "Pepsodent Complete 8, with a Zinc Mineral formula that can clean $99 \%$ of bad bacteria that hide in the entire mouth area. Just 1 toothpaste can give you and your family 8 benefits while protecting your best smile for up to 18 HOURS! Pepsodent Complete 8 is ready to provide \#Covering protection for your smile and your family". It also shows that this advertisement tries to persuade consumers to focus on the ingredients in it and its uses. Here, the advertisement shows that the product contains zinc for gum health, freshens breath, protects against dental plaque for up to 18 hours * and fights bacterial coating, and is known as an antibacterial agent.

In advertisement number 3 is written "Apart from keeping your little one's body clean during and after bathing with Zwitsal, make sure you give him extra protection with other Zwitsal products. Like keeping your little one's clothes, it is also very important to do. Let's use Zwitsal Baby Fabric Detergent and Zwitsal Baby Fabric Softener with a distinctive Zwitsal aroma. These cleaners and fabric softeners contain Green Tea and Aloe Vera, so these two products make your little one's clothes soft, fragrant, and comfortable to wear". It also shows that this advertisement tries to persuade consumers to focus on the ingredients in it and its uses. Here, the advertisement shows that the product contains Green Tea and Aloe Vera. 


\section{Journal of Pragmatics Research}

Vol. 3, No. 2 (2021), pp.108-130

E-ISSN: $2656-8020$

Website: http://e-journal.iainsalatiga.ac.id/index.php/jopr/index

\section{Table 4. Persuasive Strategy Used in Beauty and Skin Care Products}

\begin{tabular}{|c|c|}
\hline \begin{tabular}{|l} 
No \\
\end{tabular} & \\
\hline 1. & $\begin{array}{l}\text { ndsindonesia Yeay! POND’S White Beauty Facial Foam menang sebagai Best Face Wash di Female } \\
\text { aily Awards } 2020 ! \text { Yuk, gunakan terus POND'S White Beauty Facial Foam! Diperkaya dengan Mirco } \\
\text { foliating technology, Vitamin B3, dan Hyaluron Acid, POND'S White Beauty Facial Foam bisa membuat } \\
\text { ijahmu jadi bersih dan glowing seharian. Bye bye kulit kusam! } \\
\text { eay! POND's White Beauty Facial Foam won as Best Face Wash at the } 2020 \text { Female Daily Awards! Come } \\
\text {, continue to use POND'S White Beauty Facial Foam! Enriched with Mirco Exfoliating technology, } \\
\text { tamin B3, and Hyaluron Acid, POND'S White Beauty Facial Foam can make your face clean and glowing } \\
\text { day long. Bye-bye dull skin!) }\end{array}$ \\
\hline 2. & $\begin{array}{l}\text { uk ke skincare routine kamu karena } \\
\text { uron dan ekstrak bunga sakura yang } \\
\text { rsih, setelah itu aplikasikan Sakura } \\
\text { r! } \\
\text { routine because it is such a game- } \\
\text { extracts picked from Japan. Before } \\
\text { ite Waterglow Mask for } 15 \text { minutes }\end{array}$ \\
\hline 3. & $\begin{array}{l}\text { ea_id } \bullet \text { Rasakan sensasi relaksasi yang bisa kamu sentuh lembu } \\
\text { sational White Lotion Radiant Rose, yang diperkaya Licorice Extra } \\
\text { tion yang mudah diserap kulit dan membuat kulit jadi halus dan lem }\end{array}$ \\
\hline 4. & $\begin{array}{l}\text { Strawberry tinggi akan kandungan vitamin B3 dan } \\
\text { mperkuat kulit dan juga mencerahkan kulit hingga } 2 x \text {. Selain itu } V\end{array}$ \\
\hline
\end{tabular}

In advertisement 1 is written "Come on, continue to use POND'S White Beauty Facial Foam! Enriched with Micro-Exfoliating technology, Vitamin B3, and Hyaluron Acid, POND'S White Beauty Facial Foam can make your face clean and glowing all day long. Bye-bye dull skin!". It also shows that this advertisement tries to persuade consumers to focus on the ingredients in it and its uses. Here, the advertisement shows that in product uses MicroExfoliating technology for a facial cleanser with micro scrubs of dead skin cells. It also contains Vitamin B3 and hyaluronic acid for moisturizing and firming the skin to keep it healthy, supple, and looking smooth. 


\section{Journal of Pragmatics Research}

Vol. 3, No. 2 (2021), pp.108-130

E-ISSN: $2656-8020$

Website: http://e-journal.iainsalatiga.ac.id/index.php/jopr/index

In advertisement 2 is written "Sakura White Waterglow with hyaluronic and cherry blossom extracts picked from Japan. Before using the mask, make sure your face is clean, then apply the Sakura White Waterglow Mask for 15 minutes and hello naturally glowing skin!”. It shows that this advertisement tries to persuade consumers to focus on the ingredients in it and its uses. Here, the advertisement shows that the product contains hyaluronic and cherry blossom extracts. It also shows that the advertisement shows the way to use the mask to the consumers for getting glowing skin naturally by using the product.

In advertisement 3 is written "NIVEA Sensational White Lotion Radiant Rose, which is enriched with Licorice Extract \& Argan Oil in an Oil-in-Lotion formula that is easily absorbed by the skin and leaves the skin smooth and moisturized for 48 hours. The fragrance of the rose is elegant, soft and soothing". It shows that this advertisement tries to persuade consumers to focus on the ingredients in it and its uses. Here, the advertisement shows that the product contains Licorice Extract \& Argan Oil for smoothing and moisturizing skin for 2 days.

In advertisement 4 is written "Strawberry is high in vitamin B3 and antioxidants so that it can strengthen the skin and also brighten the skin up to 2x. Besides, Vaseline Body Yogurt is also enriched with prebiotics and also Vaseline Jelly. Both are combined to strengthen defense and also improve skin moisture". It shows that this advertisement tries to persuade consumers to focus on the ingredients in it and its uses. Here, the advertisement shows that the product contains vitamin B3 and antioxidants from strawberry, prebiotics, and petroleum jelly for strengthening, brightening, and moisturizing skin.

\section{DISCUSSION}

There is some previous study that has been published that is related to persuasive strategies. First, a study was written by (Alfian et al., 2019). This analysis aimed to identify the Persuasion Techniques used by Dr. Zakir Naik in his Oxford Union Speech on Islam and the 21st Century. There are 10 data indicated as a rationalization technique, 2 data indicated as identification, 8 data indicated as a suggestion, 4 data indicated as conformity, 1 indicated as compensation, 16 indicated as projection, and 15 indicated as displacement. The outcome of this analysis shows forms of persuasive strategies in expression. In Dr. Zakir Naik's voice, the ways of persuasive 


\section{Journal of Pragmatics Research}

Vol. 3, No. 2 (2021), pp.108-130

E-ISSN: $2656-8020$

Website: http://e-journal.iainsalatiga.ac.id/index.php/jopr/index

strategies are applied as an appeal to emotion, 9 as facts, 7 as a personal character. Second, a study was written by (Wijaya \& Tedjaatmadja, 2017). This research was to define the persuasive strategies used by $\mathrm{X}$ insurance agents in the prospecting of clients and to expose the discrepancies and similarities between persuasive strategies used by an insurance agent in the prospecting of clients of the same age and older clients. The study shows that the age of consumers does not necessarily change the way insurance brokers look at their customers. Third, a study was written by (Firmansyah \& Kuntjara, 2016). This research is to find out the kinds of persuasion techniques that were used in the infomercial of the Agung Sedayu Party. The study shows that using empathy to reassure 1611 is the most dominant convincing technique used by the hosts $(31.8 \%)$. In comparison, the most dominant convincing tactic used by the delegate team is to boost credibility $(22.3 \%)$.

The purpose of the persuasion strategies in this research is different from the previous studies. For example, in the first study, the persuasive strategy focuses on identification, suggestion, conformity, compensation, projection, and displacement. In the second study, the persuasive strategy focuses on prospecting and exposing the discrepancies and similarities between persuasive strategies for both two parties. In the third study, the persuasive strategy focuses on convincing the delegate team. This research uses persuasive rationalization strategy in these advertisements: 1) to persuade consumers to focus on the quality and technology of the product used, 2) to persuade consumers to focus on the ingredients in the medicine and its uses, also tries to get consumers to focus on the causes and drugs that must be consumed, 3) to persuade consumers to focus on the high standards and technology to produce the product and quality of ingredients of the products that can be consumed, 4) to persuade consumers to focus on the ingredients in it and its benefits to be used, and 5). to persuade consumers to focus on the ingredients in it and its benefits to be used. Those advertisements are expected to be a differentiator from other similar products.

In Instagram Captions' found in the selected brands' product, it is found the persuasive strategy in posting their captions such as persuasive strategy used in "Mineral Water" products, "Medicine" products, "Food and Drink" products, "Household" products, and "Beauty and Skin Care" products. In the "Mineral Water" product, the persuasive strategy found in Instagram 
Journal of Pragmatics Research

Vol. 3, No. 2 (2021), pp.108-130

E-ISSN: $2656-8020$

Website: http://e-journal.iainsalatiga.ac.id/index.php/jopr/index

captions from "sehataqua॰, le_mineraleid $\bullet, \quad$ nestlepurelife_id $\bullet, \quad$ pristine8.id $\bullet$, and amidisindonesia $\bullet$. The persuasive rationalization strategy in these advertisements tries to persuade consumers to focus on the quality and technology of the product used. In the "Medicine" product, the persuasive strategy is found in Instagram captions from "antangin_id॰, panadolid $\bullet$, tolak_angin $\bullet$, redoxonid $\bullet$. The persuasive rationalization strategy in these advertisements tries to persuade consumers to focus on the ingredients in the medicine and its uses, also tries to get consumers to focus on the causes and drugs that must be consumed. In "Food and Drink" product, the persuasive strategy found in Instagram captions from

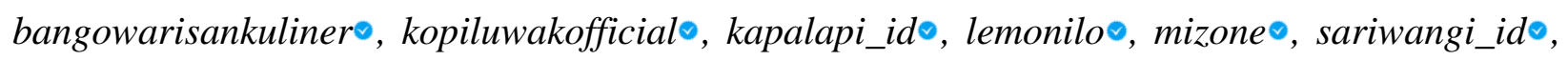
miloindonesia ${ }^{\circ}$, and anlene_indonesia ${ }^{\bullet}$. The persuasive rationalization strategy in these advertisements tries to persuade consumers to focus on the high standards and technology to produce the product and quality of ingredients of the products that can be consumed. In "Household" products, the persuasive strategy is found in Instagram captions from "rinso॰, tanyapepsodent ${ }^{\circ}$, zwitsal_id $\bullet$. The persuasive rationalization strategy in these advertisements tries to persuade consumers to focus on the ingredients in it and its benefits to be used. In "Beauty and Skin Care" products, the persuasive strategy found in Instagram captions from "pondsindonesia $\bullet$, garnierindonesia $\bullet$, nivea_id $\bullet$, and vaselineid $\bullet "$. The persuasive rationalization strategy in these advertisements tries to persuade consumers to focus on the ingredients in it and its benefits to be used.

Those products' advertisements are offered in the form of goods. Advertising is a communication made by someone to provide attractive information and offers so that the public will feel interested and motivated to use the products offered. Those advertisements use language and words that persuade someone to be motivated or interested in using the products and services that have been offered. Advertising is often associated with persuasive communication because advertising aims to invite, encourage, influence. A persuasive speech act is a communication that is carried out to influence, change behavior, attitudes, and thinking patterns. This communication is also used in business matters as a way of providing an offer from a seller to his consumer.

Those advertisements use rationalization in their persuasion strategy. In rational, the advertiser uses persuasive sentences that make sense about the product being offered. 
Journal of Pragmatics Research

Vol. 3, No. 2 (2021), pp.108-130

E-ISSN: $2656-8020$

Website: http://e-journal.iainsalatiga.ac.id/index.php/jopr/index

Rationalization in persuasion will work best if the advertiser knows the consumers' needs and wants, as well as their attitudes and beliefs. The characteristic that stands out in this technique is the involvement of reason or deep thought. Rationalization here means to make a sense. This focuses on what the advertiser is saying or writing. In this strategy, the advertiser needs statements that logic that can be accepted by the consumers. Rationalization also shows something by giving some logical statement or reason that can be accepted by logic.

This persuasive sentence is widely used in types of public service advertisements that aim to invite and influence readers to act according to what we expect through the ad text sentence. The persuasive language contains messages to generate rational appeal so that it gets the attention of consumers and is based on factual. It is associated with high involvement decision making, namely the recipient of the message is motivated to be able to process information that displays the benefits of the product and the benefits of the product as well as presenting reasonable arguments, including factual.

Rationalization is a strategy of using the basic mind to have a reason. This approach has been used by some claims to make the customer feel confident with the product. The advertiser needs to know what the expectations, preferences, wishes, and behaviors, and values of the consumer are. The advertising will explain the product's efficiency by learning certain things. Rationalization aims to show the truth of the benefits of a product to attract consumers so that potential consumers will choose the product. Rational as a persuasion technique can be limited as a process of using reason to justify a problem, where the basis or reason is not a direct cause of the problem. In rationalization, the advertiser uses persuasive sentences that make sense about the product being offered.

\section{CONCLUSION}

The content of the message in the advertisement must emphasize facts and logical persuasion. Rational also tends to be informative and rational in their advertising, in general, to

try to convince consumers that the product has special benefits that satisfy consumers. From the findings and discussion in this research, it is found that the persuasive strategy used in "Mineral Water", "Medicine", "Food and Drink", "Household", and "Beauty and Skin Care" products. 
Journal of Pragmatics Research

Vol. 3, No. 2 (2021), pp.108-130

E-ISSN: $2656-8020$

Website: http://e-journal.iainsalatiga.ac.id/index.php/jopr/index

The "Mineral Water" ads try to persuade consumers to focus on the quality and technology used. In "Medicine" products, they focus on the ingredients in the medicine and its uses, also on the causes and drugs that must be consumed. For "Food and Drink" products, they persuade consumers to see the high standards and technology to produce the product and quality of ingredients. In "Household" products, the ads persuade consumers by emphasizing the ingredients and their benefits. A similar focus is also identified in the ads of "Beauty and Skin Care" products.

Sometimes the advertising language used is unreasonable or does not use the correct Indonesian language. Advertising language should be persuasive and rational and always try to arouse emotions in the reader or listener. The goal is that those who become the target of the advertisement (consumers) do something or act following the ad's mandate. Therefore, in the language of advertising, the words used are in the form of seduction, suggestion, or invitation that can arouse curiosity. The product packaging is made attractive and placed appropriately, undoubtedly the advertisement will succeed in influencing readers or listeners.

\section{REFERENCES}

Alfian, A., Santi, C. F., \& Sari, N. (2019). Persuasive Strategies Used by Dr. Zakir Naik in his Speech in Oxford Union with Theme "Islam and the 21st Century." English Language, Linguistics, Literature, And Education Journal, 1(1), 32-44. http://ellture.fah.uinjambi.ac.id

Aziz, S. A. H., \& Othman, S. K. (2020). Speech Acts Uses in Persuasion and Deception in Marketing Discourse. Journal of the University of Babylon for Humanities, 28(6), 12.

Bajaj, R. (2020). DIY Instagram Marketing. Raveena Bajaj.

Finnemore, M., \& Goldstein, J. (2013). Back to Basics: State Power in a Contemporary World. Oxford University Press.

Firmansyah, I., \& Kuntjara, E. H. (2016). Persuasive Strategies Used by Agung Sedayu Group in the Infomercial, Metro TV. Kata Kita, 4(2), 12-20. 
Journal of Pragmatics Research

Vol. 3, No. 2 (2021), pp.108-130

E-ISSN: $2656-8020$

Website: http://e-journal.iainsalatiga.ac.id/index.php/jopr/index

Fitria, T. N. (2020). Analysis of Deixis in the Subtitle Movie of "First Kiss". LET: Linguistics, Literature and English Teaching Journal, 10(1), 111-132.

Fitria, T. N. (2015). Analysis Of Speech Act In Doraemon "Stand By Me” Movie. ResearchGate.

Fitria, T. N. (2020). An Analysis of Code Mixing of an Australian Youtuber "Dave Jephcott" in His Instagram “Londo Kampung”. Rainbow: Journal of Literature, Linguistics and Culture Studies, 10(1), 57-68.

Fitria, T. N. (2019). An analysis of directive speech act found in "koi mil gaya" movie. Journal of Pragmatics Research, 1(2), 89-99.

Fitria, T. N. (2019b). An Analysis of Directive Speech Act Found in "Koi Mil Gaya" Movie. Journal of Pragmatics Research, 1(2), 89-99. https://doi.org/10.18326/jopr.v1i2.89-99

Given, L. M. (2008). The Sage Encyclopedia of Qualitative Research Methods: A-L ; Vol. 2, M-Z Index. SAGE.

Given, L. M. (2015). 100 Questions (and Answers) About Qualitative Research. SAGE Publications.

Goossens, L., Pauwels, P., Rudzka-Ostyn, B., Simon-Vandenbergen, A.-M., \& Vanparys, J. (1995). By Word of Mouth: Metaphor, metonymy and linguistic action in a cognitive perspective. John Benjamins Publishing.

Haverkate, H. (2002). The Syntax, Semantics, and Pragmatics of Spanish Mood. John Benjamins Publishing.

Johansen, J. D., \& Larsen, S. E. (2005). Signs in Use: An Introduction to Semiotics. Routledge.

Kardela, H., Sullivan, W. J., \& Głaz, A. (2004). Perspectives on Language. Uniwersytetu Marii Curie-Skłodowskiej.

Keraf, G. (2004). Argumentasi dan Narasi. Gramedia Pustaka Utama.

Krapova, I., \& Joseph, B. (2018). Balkan Syntax and (Universal) Principles of Grammar. Walter de Gruyter GmbH \& Co KG.

Łyda, A., \& Drożdż, G. (2014). Dimensions of the Word. Cambridge Scholars Publishing.

Macarro, A. S., \& Peñuelas, A. B. C. (2014). New Insights into Gendered Discursive Practices: Language, Gender and Identity Construction. Universitat de València. 
Journal of Pragmatics Research

Vol. 3, No. 2 (2021), pp.108-130

E-ISSN: $2656-8020$

Website: http://e-journal.iainsalatiga.ac.id/index.php/jopr/index

Neergaard, H., \& Ulhøi, J. P. (2007). Handbook of Qualitative Research Methods in Entrepreneurship. Edward Elgar Publishing.

Onuf, N. (2013). Making Sense, Making Worlds: Constructivism in Social Theory and International Relations. Routledge.

Pauwelyn, J., Wessel, R., \& Wouters, J. (2012). Informal International Lawmaking. OUP Oxford.

Pérez-Hernández, L. (2020). Speech Acts in English: From Research to Instruction and Textbook Development. Cambridge University Press.

Serafinelli, E. (2018). Digital Life on Instagram: New Social Communication of Photography. Emerald Group Publishing.

Wijaya, O. O., \& Tedjaatmadja, H. M. (2017). Persuasive Strategies Used by Insurance Agents in Prospecting Customers Based on Age Factor. Kata Kita, 5(1), 15-20. https://doi.org/10.9744/katakita.5.1.15-20

Yue, Y. (2009). Persuasive strategies: An intercultural perspective. Proceedings of the 2009 International Online Language Conference (IOLC 2009), 235-243. http://ecite.utas.edu.au/60535

Zhang, G., \& Parvaresh, V. (2019). Elastic Language in Persuasion and Comforting: A CrossCultural Perspective. Springer Nature. 